УДК 640.432.011.22:005.591.6:005.332.4

DOI 10.15673/fie.v13i4.2194

\author{
Коркач Г.В. \\ доктор технічних наук, доцент \\ кафедра готельно-ресторанного бізнесу \\ E-mail:kor2007@ukr.net \\ ORCID 0000-0002-9147-5508 \\ Нікітчіна Т.І. \\ кандидат технічних наук, доцент \\ кафедра готельно-ресторанного бізнесу \\ E-mail:nikitchinati@ukr.net, \\ ORCID 0000-0002-1034-3483
}

\author{
Котузаки О.М. \\ кандидат технічних наук, доцент \\ кафедра готельно-ресторанного бізнесу \\ E-mail:elena1kotuzaki@gmail.com \\ ORCID 0000-0001-9846-8995
}

Шунько Г.С.

кандидат технічних наук, старший викладач кафедра готельно-ресторанного бізнесу

Одеська національна академія харчових технологій вул. Канатна 112, м. Одеса, Україна, 65039

E-mail:annashunko@gmail.com ORCID 0000-0003-4985-2688

\title{
ТЕХНОЛОГІЧНІ ІННОВАЦІЇ В РЕСТОРАННОМУ БІЗНЕСІ ДЛЯ ЗАБЕЗПЕЧЕННЯ КОНКУРЕНТОСПРОМОЖНОСТІ ЗАКЛАДУ
}

Інновації сприяють формуванню нових знань, технологій, відкриттів, народжують інноваційні технології, що дозволяють утримати та залучити споживачів, послуги, виводити підприємство на новий рівень та ринки. Ресторанні заклади прагнуть в умовах жорсткої ринкової конкуренції надати клієнтам якісні послуги харчування та обслуговування. Від харчування вирішальним чином залежить здоров'я та благополуччя людини. Сьогодні споживач, крім безпеки, все більше цікавиться впливом різних харчових продуктів на його здоров'я. Тому перед закладами ресторанного господарства стоїть задача не тільки смачно нагодувати клієнта, але і корисно. У роботі досліджено вплив продуктів переробки топінамбуру, які володіють пребіотичними властивостями, на якісні показники печива. Визначено вплив добавки на показники якості клейковини і встановлено покращення органолептичних показників печива з пребіотиком. Впровадження технологічної інновації, розширення меню, запровадження у закладі здорового харчування дозволить викликати інтерес до цього закладу, утримати постійних клієнтів і залучити нових, що буде сприяти посиленню переваг та конкурентоспроможності.

Ключові слова: технологічні інновації, ресторанний бізнес, здорове харчування, печиво, конкурентоспроможність.

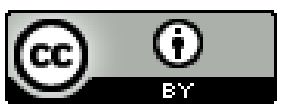

This work is licensed under a Creative Commons Attribution 4.0 International License http://creativecommons.org/licenses/by/4.0/
Постановка проблеми та її зв'язок з важливими науковими та практичними завданнями. Індустрія харчування $є$ на сьогоднішній день однією 3 галузей економіки, що динамічно розвивається. Вона спрямована на задоволення потреб практично різних сегментів споживачів (клієнтів, користувачів). Підприємства індустрії харчування вирішують певні глобальні соціальні, економічні завдання регіону, країни та світової спільноти.

Збільшення ділової активності та купівельної спроможності населення призвело до значного зростання кількості підприємств індустрії харчування, зокрема закладів ресторанного господарства. Прискорений ритм життя змушує найбільш платоспроможну частину працездатних громадян харчуватися поза домом. Індустрія харчування покликана забезпечити населення необхідною якісною кулінарною продукцією, стандартними послугами та сервісом.

У сучасному світі ресторанні заклади піддалися серйозному випробуванню. Економічна криза, що викликана пандемією (COVID-19, 2020 р.), завда- ла сильного удару по ресторанному бізнесу і не лише по ньому. Але, незважаючи на поточну складну ситуацію через карантинні обмеження, що діють у сфері гостинності України на сьогоднішній день, ресторанний бізнес бореться, пристосовується, змінюється та намагається жити

За даними Ресторанного консалтингу, якщо на початку 2020 року в Україні працювало майже 18 000 закладів громадського харчування, то вже у 2021 році десь 15000 [1]. Успішне відновлення роботи та отримання прибутку у ресторанних закладах можливо лише тоді, коли вони значно покращать свою роботу, впроваджуючи інноваційні проекти, технології та послуги.

Аналіз останніх публікацій по проблемі. Вперше про інновації заговорили у зв'язку з науковим осмисленням підприємництва, виділяючи інноваційність в якості основної характерної риси. Засновником цього напряму є Йозеф Шумпетер [2]. У розвиток вчення про інноваційність значний внесок роблять сучасні дослідники ближнього зарубіжжя та України: 
Беляєв Ю.М. [3], Фатхутдінов Р.А. [4], Аврамова О.С. [5], Іванова В.В. [6], Іжевський В.В. [7], Найдюк В.С [8], П'ятницька Г.Т. [9,10]. Особливості інноваційної діяльності і підприємств ресторанного господарства висвітлюються у роботах зарубіжних вчених: М. Ottenbacher та J. Gnotn [11], Ivkov M. [12], Godinsky M. [13], Backman M [14]. У останні роки споживач стає дуже вибагливим до свого харчування, тому що від нього у великій мірі залежить здоров'я та працездатність. Одним із інноваційних напрямків у закладах ресторанного господарства $\epsilon$ розробка новітніх харчових продуктів для функціонального харчування. Слід зазначити, що даний напрямок не набув належного застосування та на сьогоднішній день $€$ "нішевим".

Формулювання цілей дослідження. Метою статті $є$ розробка (створення) технологічних інновацій шляхом конструювання борошняних кондитерських виробів функціонального призначення для підвищення конкурентоспроможності закладів ресторанного господарства. тування.

Виклад основних результатів та їх обгрун-

Якісні перетворення в економіці України, зумовлені становленням ринкових відносин, призвели до зростання конкуренції у всіх сферах життя, зокрема у сфері індустрії харчування. У сучасних умовах виробництва виробляти конкурентну продукцію неможливо без використання інновацій, що пропонують застосування нових методів та прийомів ведення бізнесу, формування перспективного стилю мислення, впровадження нових технологічних досягнень у виробничу діяльність.

У якості мотивації підприємств індустрії харчування до розробки та впровадження інновацій виступають такі цілі: залучення клієнтури, підвищення якості продукції та різноманітних послуг, розробка нових страв та виробів для здорового харчування. Підприємницький підхід, новаторські рішення та реалізація інновацій можуть забезпечити успіх та конкурентоспроможність підприємств індустрії харчування, зокрема ресторанів.

В Законі України «Про інноваційну діяльність» визначено механізми впровадження інноваційної діяльності у суспільстві та заходи, що орієнтують його на інноваційний розвиток, а саме: створення необхідних (правових, економічних та організаційних) умов для оновлення, подальшого розвитку і використання науково-технологічного потенціалу країни, відродження духовності, інтелекту держави, формування інноваційної культури нації тощо [15].

Розробка функціональних продуктів харчування нового покоління є інноваційним напрямком у ресторанному бізнесі, що має надзвичайно важливе практичне значення та соціальну ефективність. Нині виникає потреба суспільства по розробці функціональних продуктів для тих груп споживачів, стан здоров'я яких потребує корекції повсякденного харчування. На найближчу перспективу такими групами споживачів можуть стати особи, які займаються переважно фізичною або розумовою працею; люди похилого віку, у тому числі такі, що мають різні захворювання; споживачі, які мають захворювання шлунковокишкового тракту, серцево-судинної системи, ожиріння різного ступеня тяжкості. Сучасні споживачі все частіше вибирають продукти, які не тільки задовольняють голод і дають необхідні поживні речовини, але мають додаткові переваги - покращують фізичне і розумове здоров'я. Тому актуальною і своєчасною потребою $є$ розробка страв і виробів 3 корисними властивостями для профілактики тих чи інших захворювань.

У меню ресторанів входять борошняні кондитерські вироби, а саме: торти, тістечка, кекси, печиво, вафлі, мафіни, ромові баба. Традиційно найбільшим попитом користується печиво. Для отримання нових видів печива, збагачених фізіологічно функціональними харчовими інгредієнтами, перспективним $\epsilon$ використання нетрадиційної сировини. В ОНАХТ розроблена технологія фракціонування окремих компонентів бульб топінамбуру, що володіють біфідогенними властивостями: водний екстракт з тонкоподрібнених бульб, що містить $3 \%$ редукувальних цукрів, 4 \% фруктоолігосахаридів зі ступенем полімеризації 3-5; розчинні пектинові речовини в кількості $0,5 \%$, азотисті речовини - 0,5\% та мінеральних речовин - 0,5\%; препарат інуліну; харчові волокна 3 твердого нерозчинного осаду, що складаються з целюлози (30\%), протопектину (25\%), геміцелюлози (20\%), білків (12,5\%) та золи $(12,5 \%)$.

$\mathrm{У}$ даній роботі використовували в якості пребіотичної добавки водний екстракт 3 бульб топінамбуру і харчові волокна 3 твердого нерозчинного осаду. Відомо, що харчові волокна, які володіють пребіотичними властивостями, мають здатність пов'язувати і виводити з організму частину токсичних речовин, що надходять 3 їжею. Пребіотики захищають кишечник від застосування патогенних мікробів, так як створюють у ньому кисле середовище, несприятливе для кишкових патогенів [16]. Пребіотичні волокна сприяють прояві імуногенних властивостей корисних бактерій у кишечнику за рахунок збільшення вироблення ними бактеріальних продуктів з імуномодулюючими властивостями, а також стимулюючи лактобацили, посилюють клітинний імунітет [17].

Приготування печива в лабораторних умовах проводилося за традиційною технологією, яка включає наступні стадії: приготування емульсії; заміс тіста, формування тіста; випікання тістових заготовок; охолодження печива. При приготуванні печива 3 введенням пребіотичної добавки відбувались наступні зміни: дозування водного екстракту топінамбуру робили на стадії приготування емульсії замість рецептурної кількості води; внесення порошку харчових волокон відбувалося на стадії замісу тіста. Масова частка порошку з топінамбуру становила 2, 4 та $6 \%$ до маси сухих речовин готового продукту.

При приготуванні емульсії вводили усі рецептурні компоненти, крім борошна та харчових волокон. Суміш перемішували протягом 7-10 хв до одержання однорідної консистенції. Приготування тіста проводили у тістомісильній машині шляхом 
змішування емульсії з сумішшю сипких компонентів: борошна та порошку з топінамбуру. Тривалість замісу становила 20-30 хв. Температура тіста не повинна перевищувати $30{ }^{\circ} \mathrm{C}$. Формували тістові заготовки вручну і випікали в печі при температурі $180 \ldots 200^{\circ} \mathrm{C}$ протягом 10-12 хв.

У ході досліджень визначали вплив порошку харчових волокон на кількість та властивості клейко- вини борошна, оскільки харчові волокна здатні вступати до міжмолекулярних взаємодій з іншими інгредієнтами цукрового печива. При вивченні якісних та кількісних змін у борошно вносили 2,4 та $6 \%$ порошку 3 харчових волокон. За стандартною методикою відмивали клейковину і визначали їі вміст і здатність чинити опір деформуючому навантаженню стиснення. Результати досліджень представлені у табл. 1 .

Таблиця 1

Вплив порошку топінамбуру на кількість і якість клейковини пшеничного борошна*

\begin{tabular}{|l|c|c|c|c|}
\hline \multirow{2}{*}{ Назва показників } & \multicolumn{3}{|c|}{ Масова частка порошку із топінамбуру, \% } \\
\cline { 2 - 5 } & 0 & 2 & 4 & 6 \\
\hline $\begin{array}{l}\text { Кількість сирої клей- } \\
\text { ковини, \% }\end{array}$ & 34 & 30 & 27 & 24 \\
\hline Розтяжність, см & 34 & 30 & 27 & світлий \\
\hline Колір & світлий & світлий & 56 & 54 \\
\hline $\begin{array}{l}\text { Стисливість, од. прил. } \\
\text { ВДК-1 }\end{array}$ & 60 & 58 & 168 & 163 \\
\hline $\begin{array}{l}\text { Гідратаційна здатність, } \\
\%\end{array}$ & 176 & 170 & & \\
\hline
\end{tabular}

*Власна розробка авторів

Як свідчать експериментальні результати, зі збільшенням масової частки харчових волокон відбувається зменшення кількості клейковини в тісті. Також при внесенні харчових волокон здатність клейковини чинити опір деформуючому навантаженню стиснення виявляється меншою, ніж у контрольного зразка. Це свідчить про іiі розслаблення та пояснюється високою водозв'язувальною здатністю харчових волокон, що проявляється при замішуванні тіста, і перешкоджає здатності клейковини до набухання й утворенню комплексів між білками клейковини та харчовими волокнами.

Зменшення кількості сирої клейковини зі збільшенням масової частки порошку з харчових волокон можна пояснити тим, що харчові волокна, пов'язуючи рецептурну кількість води, перешкоджають набуханню білків, що, у свою чергу, сприяє вимиванню їх із проби борошна разом з крохмалем та іншими компонентами. Можна припустити, враховуючи якість клейковини, що відмивається значна частина глютенінової фракції, яка є гумоподібною, короткорозтяжною структурою при великому опорі деформацiї.

Отже, одержані результати дають змогу констатувати, що внесення харчових волокон в цукрове тісто дозволить покращити його пластичні властивості, і як наслідок, одержати готові вироби відмінної якості.

При розробці нових видів виробів необхідно враховувати їх конкурентоспроможність, тобто за умови відповідності вимог безпеки і якості ключовим у виборі споживача буде смак та інші органолептичні показники. Тому важливо було дослідити як введення до складу печива пребіотичної добавки впливає на його органолептичні властивості.

Результати визначення органолептичних показників, що характеризують споживчу привабливість продукту, наведені у табл. 2.

Таблиця 2

Органолептична оцінка якості печива

\begin{tabular}{|c|c|c|c|c|}
\hline \multirow[t]{2}{*}{ Показники якості } & \multicolumn{4}{|c|}{ Масова частка харчових волокон, \% і водний екстракт із топінамбуру } \\
\hline & 0 & 2 & 4 & 6 \\
\hline Поверхня & \multicolumn{4}{|c|}{ Гладка, без здуття і підривів } \\
\hline Колір & $\begin{array}{c}\text { Рівномірний світ- } \\
\text { ло-золотистий }\end{array}$ & $\begin{array}{l}\text { Рівномірний світ- } \\
\text { ло-золотистий }\end{array}$ & $\begin{array}{c}\text { Рівномірний } \\
\text { золотистий відтінок }\end{array}$ & $\begin{array}{c}\text { Рівномірний світло- } \\
\text { коричневий }\end{array}$ \\
\hline Форма & \multicolumn{4}{|c|}{ Края печива рівні, без вм’ятин та пошкоджень } \\
\hline Вигляд у розломі & \multicolumn{4}{|c|}{ Пропечені вироби із рівномірною пористістю, без слідів непромісу } \\
\hline Смак, запах & $\begin{array}{c}\text { Солодкий, без сто- } \\
\text { ронніх присмаків } \\
\text { та запахів }\end{array}$ & Солодкі & із легким присмаком & опінабура \\
\hline
\end{tabular}

*Власна розробка авторів

Для більш повного опису смаку і запаху продукту та його оцінки використовували профільний метод, який найбільш доцільний при розробці нових рецептур продуктів і ідентифікації джерела появи у продуктах сторонніх властивостей (рис.1). 


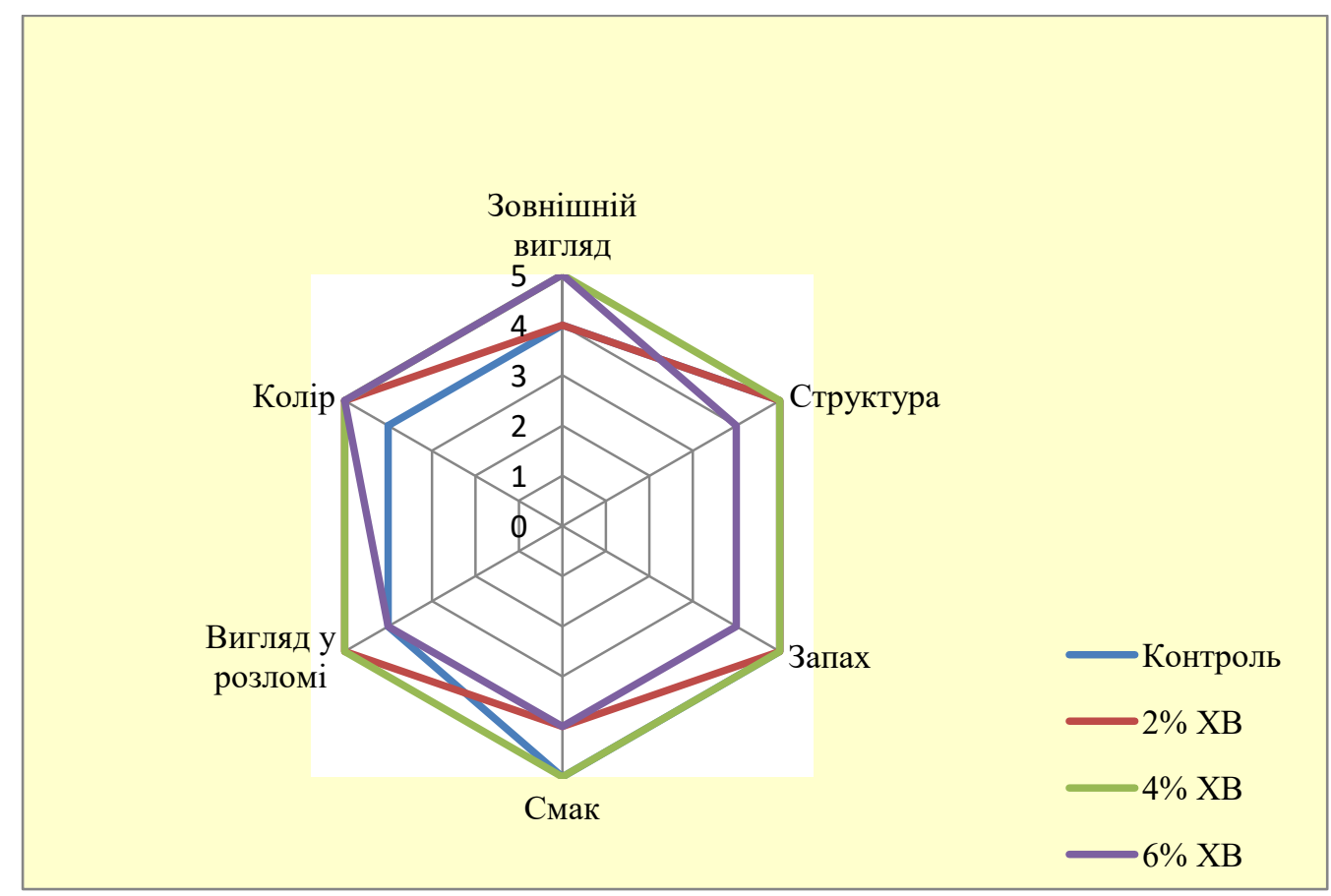

Рис. 1. Профілограма органолептичних показників якості печива

* власна розробка авторів

Результати сенсорного аналізу свідчать, що розроблені види печива 3 пребіотичною добавкою вигідно відрізняються від контролю за смаковими показниками, так як мають оригінальний присмак топінамбуру, покращується колір виробів та структуpa.

Отже, комплекс проведених досліджень свідчить, що внесення до рецептури печива пребіотичної добавки дозволить не тільки покращити якісні показники дослідних зразків готових виробів, але і дозволить впровадити в меню ресторанних закладів печиво 3 функціональними властивостями, а саме, для нормалізації мікрофлори кишечника.

Висновки та перспективи подальших досліджень. Для підвищення ефективності діяльності підприємства та його конкурентоспроможності в умовах ринкової економіки існує потреба у постійній модернізації продукту або послуги, яка досягається за рахунок впровадження інновацій. Запропонований інноваційний підхід, який спрямований на розробку нового виду печива 3 функціональними властивостями, відповідного потребам ринку, є одним із найважливіших факторів, що впливають на конкурентоспроможність підприємств ресторанного бізнесу та одержання прибутку. Впровадження технологічної інновації, розширення меню, запровадження у закладі здорового харчування дозволить викликати інтерес до цього закладу, утримати постійних клієнтів і залучити нових.

\section{Література}

1. Как в последний раз: в Украине выросла посещаемость кафе и ресторанов // VESTI.UA: сайт газеты Вести. 2021. 12 марта. URL: https://vesti.ua/strana/kak-v-poslednij-raz-v-ukraine-vyrosla-poseshhaemost-kafe-irestoranov (дата звернення 20.10.2021).

2. Шумпетер Й. Теория экономического развития. М.: Прогресс, 1982. 34 с.

3.Беляев Ю.М. Инновационный менеджмент: учебн. для бакал. М: Дашков и К, 2013. 220 с.

4. Фатхутдинов Р.А. Инновационный менеджмент: учебн. для вузов. СПб: Питер, 2013. 448 с.

5. Аврамова О.С., Кізь Е.С. До проблеми визначення інновації // Вісник Нац. техн. ун-ту "ХПІ". Зб. наук. пр. темат. вип.: Актуальні проблеми розвитку українського суспільства. Харків : НТУ "ХПІ". 2011. № 30. С. 161-165.

6. Іванова В.В. Дослідження теорії поняття інновації // Економіка промисловості. 2009. № 4. С. 80-86. URL: http://nbuv.gov.ua/UJRN/econpr_2009_4_15 (дата звернення 20.10.2021).

7. Іжевський В.В. Економічна суть інноваційної діяльності підприємств торгівлі та ресторанного господарства [Електронний ресурс] // Науковий огляд: електрон. версія журн. 2021. URL: http://intkonf.org/izhevskiyvv-ekonomichna-sut-innovatsiynoyi-diyalnosti-pidpriemstv-torgivli-ta-restorannogo-gospodarstva/ (дата звернення 20.10.2021). 
8. Найдюк В.С. Сутність та передумови інноваційного розвитку підприємств// Маркетинг і менеджмент інновацій. 2013. № 3. С. 251-263.

9. П'ятницька Г.Т. Ресторанне господарство України: ринкові трансформації, інноваційний розвиток, структурна переорієнтація: монографія. К.: Київ. нац. торг-екон. ун-т, 2007. 465 с.

10. П'ятницька Г.Т., П’ятницька Н.О. Вплив інноваційних змін на діяльність підприємств ресторанного господарства // Економіка розвитку. 2013. № 1(65). С.122-126.

11. Ottenbacher M., Gnoth J. How to develop successful hospitality innovation // Cornell Hospitality Quarterly. 2005 . Vol.46 (2). P. 205-222. doi: 10.1177/0010880404271097

12. Ivkov M., Blesic I., Simat K. Innovations in the restaurant industry: An exploratory study. Ekonomica Poljoprivrede. 2016. V.63, №4. P. 1169-1186. DOI:10.5937/ekoPolj1604169I.

13. Godinsky M. How Foodservice Innovation Has Changed in Response to Coronavirus // Euromonitor international. 2021. 19 may. URL: https://www.euromonitor.com/article/how-foodservice-innovation-has-changed-inresponse-to-coronavirus (viewed on: 1.11.2021).

14. Backman M., Klaesson J., Öner Ö. Innovation in the Hospitality Industry: Firm or Location? // Tourism Economics. 2017. Vol. 23 (8). P. 1591-1614. doi: 10.1177/1354816617715159

15. Про інноваційну діяльність: Закон України від 04.07.2002 р. № 40-IV. За станом: 05.12.2012. URL:https://zakon.rada.gov.ua/laws/show/40-15\#Text (дата звернення 1.11.2021).

16. Ардатская М.Д. Пробиотики, пребиотики и метабиотики в коррекции микроэкологических нарушений кишечника // Медицинский совет. 2015. № 13. С. 94-99.

17. Wilson B, Whelan K. Prebiotic inulin-type fructans and galacto-oligosaccharides: definition, specificity, function, and application in gastrointestinal disorders // Journal of Gastroenterology and Hepatology. 2017. Vol. 32 (1). P.64-68. doi: 10.1111/jgh.13700.

Стаття надійшла 7.11.2021

Стаття прийнята до друку 21.11.2021

Доступно в мережі Internet 30.12.2021

Korkach $\mathrm{H}$.

Doctor of Technical Science, Associate Professor

Department of Hotel and Restaurant Business

E-mail:kor2007@ukr.net

ORCID 0000-0002-9147-5508

Nikitchina T.

PhD, Associate Professor

Department of Hotel and Restaurant Business

E-mail:nikitchinati@ukr.net,

ORCID 0000-0002-1034-3483

\author{
Kotuzaki O. \\ PhD, Associate Professor \\ Department of Hotel and Restaurant Business \\ E-mail:elena1kotuzaki@gmail.com \\ ORCID 0000-0001-9846-8995 \\ Shunko H. \\ PhD., Assiatant \\ Department of Hotel and Restaurant Business \\ Odessa National Academy of Food Technologies \\ Kanatna str., 112, Odesa, Ukraine, 65039 \\ E-mail:annashunko@gmail.com \\ ORCID 0000-0003-4985-2688
}

\section{TECHNOLOGICAL INNOVATIONS IN THE RESTAURANT BUSINESS FOR PROVISION THE COMPETITIVENESS OF RESTAURANTS}

In the current economic situation and competition among various establishments of the restaurant industry, one of the main tasks facing the enterprise is to retain regular customers and attract new ones. To achieve this goal, it is necessary to introduce various innovative technologies into the restaurants. Being in these conditions, specialists need to carry out experiments with the menu, need to provide new specialties of the house, products with useful properties for preventive and healthy nutrition. Lifestyle and nutrition are the most important factors ensuring human health, people's ability to work, the ability to withstand external unfavorable factors. In recent years, a significant deterioration in the health of the population has been observed in Ukraine, therefore, food products with functional ingredients are being developed and for sure it can improve their physiological properties and contribute to the prevention of some diseases. These ingredients include prebiotics, the consumption of which leads to specific changes in the composition of the intestinal microflora and in such a way benefits human health.

The article explores the effect of Jerusalem artichoke processing products (aqueous extract from Jerusalem artichoke tubers and dietary fiber from solid insoluble sediment) in the cookie recipe on the quality indicators of gluten and on the change in the organoleptic characteristics of the finished product. Samples of biscuits were obtained with the replacement of water in their composition with an aqueous extract from Jerusalem artichoke tubers and the introduction of the mass fraction of powder from dietary fiber - 2, 4, 6\% to the dry matter mass of the finished product. The experimental data obtained indicate that the introduction of a 
complex prebiotic additive leads to a change in the quantitative and qualitative indicators of gluten, which will improve the plastic properties of the sugar dough and will make it possible to obtain high-quality finished products.

The results of sensory analysis indicate that the developed types of biscuits with a prebiotic additive compare favorably with the control in terms of taste indicators, since they have the original taste of Jerusalem artichoke, and the product color and structure are improved.

Innovation is a powerful action to help with overcoming recession, to provide structural adjustment and to develop new foods and products. The introduction of the proposed technological innovation will expand the range of products for "healthy" nutrition, thereby contributing to increase in the attractiveness of the enterprise and a change in the concept adapted to modern market requirements, which will significantly increase the efficiency of work and competitiveness in the restaurant business.

Key words: technological innovation, restaurant business, healthy food, cookies, competitiveness.

\section{References}

1. Kak v posledniy raz: v Ukraine vyirosla poseschaemost kafe i restoranov . VESTI.UA. (2021, March 12). Retrieved October 20, 2021, from https://vesti.ua/strana/kak-v-poslednij-raz-v-ukraine-vyrosla-poseshhaemost-kafe-irestoranov

2. Shumpeter, Y. (1982). Teoriya ekonomicheskogo razvitiya. Progress.

3.Belyaev, Yu. M. (2013). Innovatsionnyiy menedzhment. Dashkov i K.

4. Fathutdinov, R. A. (2013). Innovatsionnyiy menedzhment. Piter.

5. Avramova, O. Ye., \& Kiz, E. S. (2011). Do problemy vyznachennia innovatsii . Visnyk Nats. tekhn. un-tu "KhPI". Zb. nauk. pr. temat. vyp.: Aktualni problemy rozvytku ukrainskoho suspilstva, (30), 161-165.

6. Ivanova, V. V. (2009). Doslidzhennia teorii poniattia innovatsii. Ekonomika Promyslovosti, (4), 80-86. Retrieved October 20, 2021, from http://nbuv.gov.ua/UJRN/econpr_2009_4_15.

7. Izhevskyi, V. V. (2021). Ekonomichna sut innovatsiinoi diialnosti pidpryiemstv torhivli ta restorannoho hospodarstva. Naukovyi ohliad. Retrieved October 20, 2021, from http://intkonf.org/izhevskiy-vv-ekonomichna-sutinnovatsiynoyi-diyalnosti-pidpriemstv-torgivli-ta-restorannogo-gospodarstva/

8. Naidiuk, V. S. (2013). Sutnist ta peredumovy innovatsiinoho rozvytku pidpryiemstv. Marketynh $i$ menedzhment innovatsii, (3), 251-263.

9. Piatnytska, H. T. (2007). Restoranne hospodarstvo Ukrainy: rynkovi transformatsii, innovatsiinyi rozvytok, strukturna pereoriientatsiia. Kyiv. nats. torh-ekon. un-t.

10. Piatnytska, H. T., \& P'iatnytska, N. O. (2013). Vplyv innovatsiinykh zmin na diialnist pidpryiemstv restorannoho hospodarstva. Ekonomika rozvytku, (1(65)), 122-126.

11. Ottenbacher, M., \& Gnoth, J. (2005). How to develop successful hospitality innovation. Cornell Hospitality Quarterly, 46(2), 205-222. doi: 10.1177/0010880404271097

12. Ivkov, M., Blesic, I., \& Simat, K. (2016). Innovations in the restaurant industry: An exploratory study. Ekonomica Poljoprivrede, 63(4), 1169-1186. doi:10.5937/ekoPolj1604169I.

13. Godinsky, M. (2021). How Foodservice Innovation Has Changed in Response to Coronavirus. Euromonitor international. Retrieved November 1, 2021, from https://www.euromonitor.com/article/how-foodserviceinnovation-has-changed-in-response-to-coronavirus

14. Backman, M., Klaesson, J., \& Öner, Ö. (2017). Innovation in the Hospitality Industry: Firm or Location? Tourism Economics, 23(8), 1591-1614. doi: 10.1177/1354816617715159

15. Pro innovatsiinu diialnist: Zakon Ukrainy vid 04.07.2002 r. № 40-IV. Za stanom: 05.12.2012. (2012). Retrieved November 1, 2021, from https://zakon.rada.gov.ua/laws/show/40-15\#Text

16. Ardatskaya, M. D. (2015). Probiotiki, prebiotiki i metabiotiki v korrektsii mikroekologicheskih narusheniy kishechnika. Meditsinskiy sovet, (13), 94-99.

17. Wilson, B, \& Whelan, K. (2017). Prebiotic inulin-type fructans and galacto-oligosaccharides: definition, specificity, function, and application in gastrointestinal disorders. Journal of Gastroenterology and Hepatology, 32(1), 64-68. doi: 10.1111/jgh.13700.

Received 7 November 2021

Approved 21 November 2021

Available in Internet 30.12.21

Цитування згідно ДСТУ 8302:2015

Коркач Г.В., Котузаки О.М., Нікітчіна Т.І., Шунько Г.С. Технологічні інновації в ресторанному бізнесі для забезпечення конкурентоспроможності закладу // Економіка харчової промисловості. 2021. Т.13, вип. 4. С. 69-74. doi 10.15673/fie.v13i4.2194

Cite as APA style citation

Korkach, H., Kotuzaki, O., Nikitchina, T., \& Shunko, H. (2021). Technological innovations in the restaurant business for provision the competitiveness of restaurants. Food Industry Economics, 13(4), 69-74. doi 10.15673/fie.v13i4.2194 